\title{
Pesticide use in the wheat-maize double cropping systems of the North China Plain:
} Assessment, field study, and implications

\author{
Brauns, Bentje; Jakobsen, Rasmus; Song, Xianfang; Bjerg, Poul Løgstrup
}

\section{Published in:}

Science of the Total Environment

Link to article, DOI:

10.1016/j.scitotenv.2017.10.187

Publication date:

2018

Document Version

Peer reviewed version

Link back to DTU Orbit

Citation (APA):

Brauns, B., Jakobsen, R., Song, X., \& Bjerg, P. L. (2018). Pesticide use in the wheat-maize double cropping systems of the North China Plain: Assessment, field study, and implications. Science of the Total Environment, 616-617. https://doi.org/10.1016/j.scitotenv.2017.10.187

\section{General rights}

Copyright and moral rights for the publications made accessible in the public portal are retained by the authors and/or other copyright owners and it is a condition of accessing publications that users recognise and abide by the legal requirements associated with these rights.

- Users may download and print one copy of any publication from the public portal for the purpose of private study or research.

- You may not further distribute the material or use it for any profit-making activity or commercial gain

- You may freely distribute the URL identifying the publication in the public portal 
30 October 2017

Submission to Science of the Total Environment

Pesticide use in the wheat-maize double cropping systems of the North China Plain: Assessment, field study, and implications

Bentje Brauns ${ }^{\mathrm{a}, \mathrm{b}, \mathrm{c}, 1, *}$, Rasmus Jakobsen ${ }^{\mathrm{d}}$, Xianfang Song ${ }^{\mathrm{b}}$, and Poul L. Bjerg ${ }^{\mathrm{a}}$

${ }^{a}$ Department of Environmental Engineering, Technical University of Denmark, Miljøvej, Building 113, 2800 Kgs. Lyngby, Denmark

${ }^{\mathrm{b}}$ Key Laboratory of Water Cycle and Related Land Surface Processes, Institute of Geographic Sciences and Natural Resources Research, Chinese Academy of Sciences, 11A, Datun Road, Chaoyang District, Beijing, 100101, China

c Sino-Danish Center for Education and Research, Niels Jensens Vej 2, 8000 Aarhus C, Denmark

${ }^{\mathrm{d}}$ Geological Survey of Denmark and Greenland, Øster Voldgade 10, 1350 Copenhagen, Denmark

* Corresponding author: benaun@bgs.ac.uk

${ }^{1}$ Present address: British Geological Survey, Maclean Building, Crowmarsh Gifford, Wallingford, Oxfordshire, OX10 8BB, UK 


\section{Abstract}

2 In the North China Plain (NCP), rising inputs of pesticides have intensified the environmental

3 impact of farming activities in recent decades by contributing to surface water and

4 groundwater contamination. In response to this, the Chinese government imposed stricter

5 regulations on pesticide approval and application, and better monitoring strategies are being developed. However, sufficient and well-directed research on the accumulation and impact of different pesticides is needed for informed decision-making.

8 In this study, current pesticide use, and recent and current research on water contamination by 9 pesticides in the NCP are reviewed and assessed. Additionally, a small-scale field study was performed to determine if residuals from currently-used pesticides in the NCP can be detected

11 in surface water, and in connected shallow groundwater. The contaminants of interest were commonly used pesticides on winter wheat-summer maize fields (the dominant cropping system in the NCP), such as 2,4-D and atrazine. Sampling took place in May, July, and October 2013; and March 2014.

Results from our literature research showed that sampling is biased towards surface water monitoring. Furthermore, most studies focus on organic chlorinated pesticides (OCPs) like the isomers of dichlorodiphenyltrichloroethane (DDT) and hexachlorocyclohexane (HCH), which were banned in China in 1983. However, currently-used herbicides like 2,4-D and atrazine were detected in river water and groundwater in all samplings of our field study. The highest concentrations of 2,4-D and atrazine were found in the river water, ranging up to 3.00 and $0.96 \mu \mathrm{g} / \mathrm{L}$, respectively. The monitoring of banned compounds was found to be important because several studies

23 indicate that they are still accumulating in the environment and/or are still illegally in use. However, supported by our own data, we find that the monitoring in groundwater and surface 
25 water of currently permitted pesticides in China needs equal attention, and should therefore be 26 increased.

27 Keywords: North China Plain; Surface water - groundwater interaction; Pesticides; Atrazine; $28 \quad 2,4-\mathrm{D}$ 


\section{Introduction}

The North China Plain (NCP) has an output of the national maize and wheat production of about $60 \%$ and $40 \%$, respectively (Zhao and Guo, 2013), which makes it a crucial area for China's domestic food supply. It is therefore also referred to as China’s bread basket. In recent decades, the total cultivated area in the NCP has decreased due to competition for land use from industry and urbanization. To continue meeting the food demands of the rapidly growing Chinese population, higher production efficiencies needed to be achieved, so that the loss of production areas could be compensated. This goal was successfully met by introducing modern agricultural practices in the 1970s and 1980s (such as the use of fertilizers and pesticides) and by increasing irrigated agriculture. On the down-side, pesticide overuse has nowadays become common and poses a risk to valuable surface water and groundwater resources (Zhang et al., 2011). This negative effect of the agricultural activities on potential drinking water is especially problematic in the provinces of the NCP because of its high population density and its relatively low amounts of available water resources (Varis and Vakkilainen, 2001). Therefore, further decline in water quantity and quality is an imminent challenge for the area (van Oort et al., 2016; Sun et al., 2012; Zheng et al., 2015).

To address the problem of agricultural water pollution by pesticides, studies in recent years have dealt with the optimization of applied pesticide doses (Zhang et al., 2013), the need to develop a systematic risk assessment approach for water pollution by pesticides (Zhao and Pei, 2012), and the enhancement of pesticide management in general (Hamburger, 2002; Wei et al., 2007; Zhen et al., 2005). Further studies on pesticide residues in waterways and agricultural soils have repeatedly detected banned organochlorine insecticides, such as hexachlorocyclohexane (HCH) and dichlorodiphenyltrichloroethane (DDT) (Feng et al., 2011; Sun et al., 2010). Risk mapping of these compounds, and the detection of potentially 
still active application and bioaccumulation, are important tasks. However, other disputed pesticides such as atrazine (which has been banned in the EU since 2004, but is legally used in China) may potentially accumulate in the environment and cause negative environmental impacts, too. Therefore, monitoring of currently permitted and applied pesticides should also be considered. This includes obtaining knowledge about pesticide choices, means of application and disposal, environmental loads, and potential environmental impacts. Based on this information, upcoming problems can be better identified, and pesticides can be chosen and applied more wisely by the farmers. However, a comprehensive overview and review of commonly applied pesticides on Chinese winter wheat-summer maize rotations (and their loads in regional water resources) are very limited, and the availability of detailed statistics on pesticide use in China is extremely low (World Bank, 2010).

Upon this background, the aim of this study was (a) to review the current use of pesticides within the NCP, (b) to assess the recent and current research and monitoring of pesticides in water resources in the NCP, (c) to perform a small-scale field study on the occurrence of currently-used pesticides in surface water and connected groundwater, (d) to assess (supported by our findings in the field study) if currently used pesticides might cause environmental problems and if this is sufficiently addressed in the current monitoring efforts , and (e) to give recommendations for future study focus within the region.

The paper includes a comprehensive review part based on publicly available information and a field investigation at Fu River (Hebei Province) in order to investigate the current pesticide use and occurrence in the NCP. The agricultural cultivation at the field site is typical for this region, and although the study is limited in time, the findings presented illustrate the limitations in the current monitoring programs and are thereby an important contribution to the recommendations and conclusions of this paper. 


\section{Material and methods}

\subsection{Field site}

A field site located at Fu River, the main incoming river to the Baiyang Lake area in Hebei Province, China, was selected as an example for the wheat-maize double cropping system in the NCP (Figure 1a-b). The vicinity of the field site to surface water was chosen in order to investigate surface water-groundwater interactions and pollution exchange between the environmental compartments. A monitoring network (consisting of four shallow groundwater wells of which three were used for pesticide sampling) was set up on an agricultural field (about 70x240 m) that extends to about $5 \mathrm{~m}$ to the river bank (Figure 1c). The agricultural plot (owned by one household) is surrounded by other fields with different ownership, but the same cropping system.
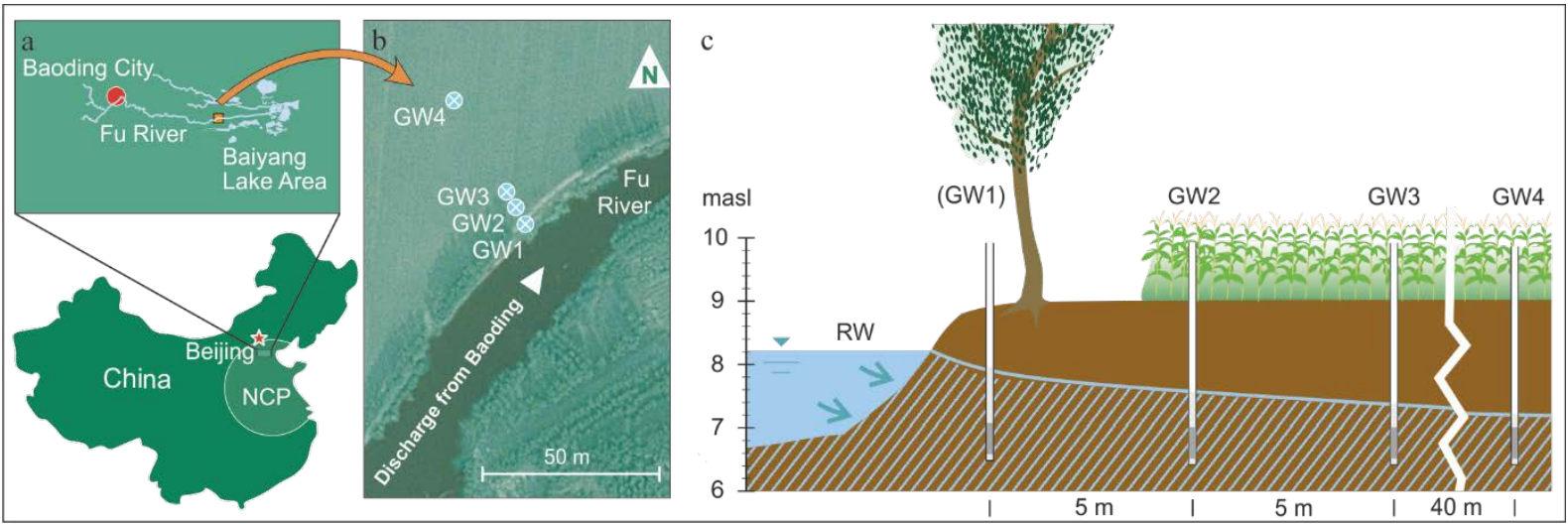

Fig. 1 (a) Location of the study site, (b) aerial view of the field site, and (c) cross-section of the sampling wells (GW1 only used for ion-analysis and general water chemistry) SINGLE-COLUMN COLOUR FIGURE

The area around Fu River is characterized by pressures from agricultural, domestic, and industrial water users. Numerous paper mills, and chemical, battery and petrochemical plants are located in the upstream part of Fu River (Hu et al., 2010a), and it receives an approximate amount of over $100000 \mathrm{~m}^{3}$ of sewage and treated wastewater from Baoding city per day (Qi et al., 2012). Previous studies show that the point and non-point pollution sources along the flow path of Fu River increase levels of organic chlorinated pesticides (OCPs), 
polychlorinated biphenyls (PCBs), and polycyclic aromatic hydrocarbons (PAHs) in the river-especially near industrial areas (Hu et al, 2010b). Studies at the river mouth (entering into Baiyang Lake) show extremely high loads of the nutrients ammonium and potassium (e.g. Zhao et al., 2012). This indicates contamination from poorly treated sewage that is led into the river (Xu et al., 2012), or possibly from direct discharge of animal manure as observed in other regions of China (Strokal et al., 2016). Temporal nitrate peaks that occur simultaneously with increased sediment loads in the river imply contamination by surface runoff of agricultural pollutants (possibly also pesticides) from adjacent field areas after rainstorms (Yan et al., 2005).

\subsection{Field site management and pesticide application}

The field site was managed according to the local customs of the area (described in more detail in Brauns et al., 2016). The successive winter wheat-summer maize rotation encompassed the growing season for wheat from October 2012 to June 2013 and that of maize from June 2013 to October 2013. Irrigation with surface water took place three times during the growing period of winter wheat. Towards the end of the study period, the region from about 1 -2 km upstream of the field site until the entrance of Fu River into the Baiyang Lake system was expected to become flooded due to unusually high summer rainfalls, which exceeded the 10 -year average by $57 \%$. Therefore, the farmers along this section of the river refrained from planting winter wheat, and the land became fallow (and flooded) during the remaining study period.

Based on interviews with the farmer, pest and weed management at the sampling site itself was done via chemical crop protection which took place twice in the winter wheat growing season (with tribenuron-methyl and dimethoate) and twice during the growing season of the summer maize (paraquat and acetochlor) via knapsack spraying. More detailed information on 
121 planting times, irrigation, and times and amounts of pesticide application can be found in

122 Appendix A Table A.2. The pesticide application in the study year was not identical to the

123 one in previous years, where atrazine had been used instead of acetochlor, and additional

124 insecticides had been applied in the fall. Application rates in the study year were mostly in

125 accordance to the recommendations on the labels of the pesticide containers. According to

126 statements from the farmer however, it seemed that the exact application amount was

127 sometimes based on avoiding leftovers in pesticide packages/bottles, rather than on judging

128 the actual needed application rate based on observation in the field, e.g. the amount of weed

129 sprouting.

130 Additional farmer interviews indicated that treatment with other substances in neighboring

131 fields was likely. For example, either 2,4-D or atrazine is often also used as post emergence

132 pesticide on winter wheat in early spring (March to April). The discovery of empty

133 containers from other substances (e.g. triadimefon) in the ambient environment of the study

134 field also indicated that additional compounds were used, at least in the surrounding area

135 (Figure 2).
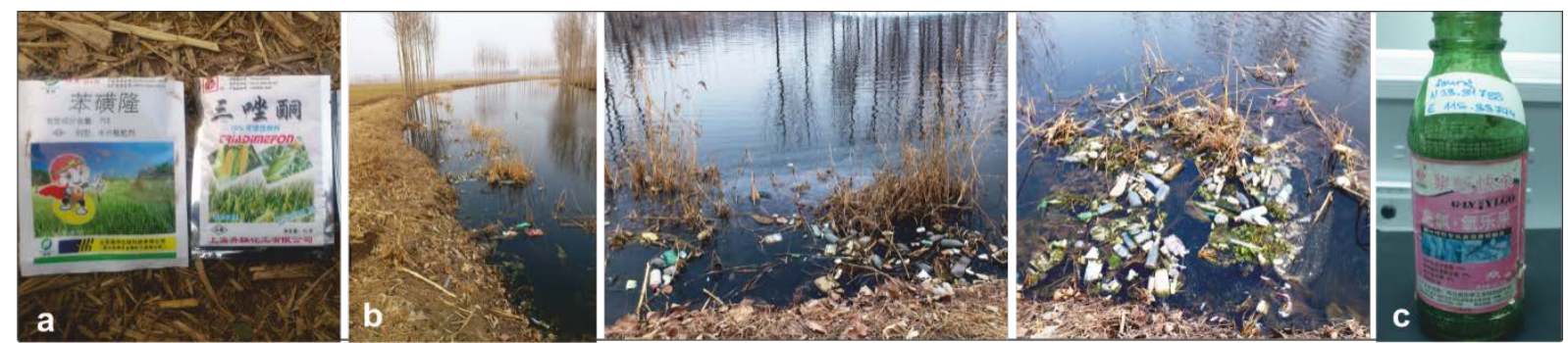

Fig. 2 (a) Improperly disposed insecticide/fungicide bags that were found at the field site (tribenuron-methyl and $2 \%$ cyhalothrin) found in the river next to the sampling site. SINGLE-COLUMN COLOUR FIGURE

\subsection{Field sampling and chemical analysis}

$1411 \mathrm{~L}$ water samples were obtained from river and from groundwater wells at a distance of 6 ,

142 11, and $41 \mathrm{~m}$ from the river (corresponding to GW2, GW3, and GW4 on Figure 1c) in May, 
143 July and October 2013, and in March 2014. The sampled water was filled to the rim into

144 brown glass bottles, immediately cooled to $4^{\circ} \mathrm{C}$, insulated, and shipped by courier to the

145 laboratory in Denmark (Eurofins, Glostrup). The samples were analyzed for a standard

146 package of different pesticides, which included some of the most universally used herbicides

147 in the NCP (and at the field) site as identified in section 3.2. (a full list of analytes is given in

148 Appendix A Table A.2). Analysis was done via gas chromatography mass spectrometry

149 (GC/MS) for chlorphenols and dichlobenil, and via liquid chromatography tandem mass

150 spectrometry (LC-MS/MS) for all other pesticides. The detection limit was $0.01 \mu \mathrm{g} / \mathrm{L}$ for all 151 compounds.

\section{3. Results and discussion}

\section{3.1. Detected pesticides in the field study}

154 Detected pesticides and their degradation products (or, in the case of 2,6-dichlorphenol,

155 intermediates) in the field study included mainly 2,4-D, 2,4-dichlorphenol (metabolite of 2,4-

156 D), 2,6-dichlorphenol (intermediate to 2,4-D), atrazine and the atrazine-metabolites

157 hydroxyatrazine, deethylatrazine, and deisopropylatrazine, terbutylazine, MCPA, bentazone,

158 DNOC, BAM (metabolite of chlorthiamid, dichlobenil and fluopicolide), and dichlorprop (see

159 Table 1). 
Table 1 Detected concentrations in $\mu \mathrm{g} / \mathrm{l}$ of selected herbicides in river water (RW) and groundwater (GW) samples (see Figure 1 for the location of the sampling points), and drinking water limits (DWL) for China and for the USA (for comparison, the standard of the European Drinking Water Directive is $0.1 \mu \mathrm{g} / \mathrm{L}$ for each individual pesticide, and $0.5 \mu \mathrm{g} / \mathrm{L}$ for the sum of all pesticides detected in the sample). Data for the Chinese standard is according to the guideline GB 5749-2006.

\begin{tabular}{|c|c|c|c|c|c|}
\hline \multirow[t]{2}{*}{ Pesticide (all values in $\mu \mathrm{g} / \mathrm{L}$ ) } & 29 May 2013 & 22 July 2013 & 07 October 2013 & 25 March 2014 & DWL \\
\hline & RW GW2GW3GW4 & RW GW2GW3GW4 & RW GW2GW3GW4 & RW GW2GW3GW4 & CN USA \\
\hline \multicolumn{6}{|l|}{ 2,4-D and related compounds } \\
\hline $2,4-D^{1}$ & $\begin{array}{llll}3.00 & 0.41 & 2.30 & 0.70\end{array}$ & $\begin{array}{llll}0.27 & 0.09 & 0.10 & 0.31\end{array}$ & $\begin{array}{llll}0.51 & 0.03 & 0.03 & 0.01\end{array}$ & $\begin{array}{llll}0.65 & 0.01 & 0.05 & 0.02\end{array}$ & $3070 *$ \\
\hline 2,4-dichlorophenol (M) & $\begin{array}{llll}0.09 & 0.14 & 0.09 & 0.14\end{array}$ & $\begin{array}{llll}0.02 & 0.10 & 0.09 & 0.07\end{array}$ & $\begin{array}{llll}0.06 & 0.03 & 0.04 & 0.03\end{array}$ & 0.01 ND ND ND & $-20 * *$ \\
\hline 2,6-dichlorophenol (I) & $\begin{array}{llll}\text { ND } & 0.02 & \text { ND } & 0.01\end{array}$ & $\begin{array}{llll}0.01 & 0.03 & 0.16 & 0.02\end{array}$ & $0.01 \mathrm{ND}$ ND ND & $0.01 \mathrm{ND}$ ND ND & $-4 * * *$ \\
\hline \multicolumn{6}{|c|}{ Atrazine and related compounds } \\
\hline Atrazine & $\begin{array}{llll}0.96 & 0.33 & 0.91 & 0.40\end{array}$ & $\begin{array}{llll}0.32 & 0.29 & 0.29 & 0.49\end{array}$ & $\begin{array}{llll}0.49 & 0.19 & 0.20 & 0.20\end{array}$ & $\begin{array}{llll}0.54 & 0.12 & 0.19 & 0.15\end{array}$ & $3^{*}$ \\
\hline Hydroxyatrazine (M) & $\begin{array}{llll}9.70 & 0.46 & 0.37 & 0.47\end{array}$ & $\begin{array}{llll}0.31 & 0.59 & 0.54 & 0.49\end{array}$ & $\begin{array}{llll}3.00 & 0.55 & 0.39 & 0.48\end{array}$ & $\begin{array}{llll}1.60 & 0.26 & 0.33 & 0.20\end{array}$ & - \\
\hline Desethylatrazine (M) & $\begin{array}{llll}0.07 & 0.04 & 0.05 & 0.04\end{array}$ & $\begin{array}{llll}0.17 & 0.09 & 0.07 & 0.16\end{array}$ & $\begin{array}{llll}0.03 & 0.01 & 0.02 & 0.04\end{array}$ & $\begin{array}{llll}0.05 & 0.03 & 0.04 & 0.08\end{array}$ & - \\
\hline Deisopropylatrazine (M) & $\begin{array}{llll}0.07 & 0.05 & 0.05 & 0.04\end{array}$ & $\begin{array}{llll}0.04 & 0.16 & 0.08 & 0.09\end{array}$ & ND ND ND 0.01 & $\begin{array}{llll}0.13 & 0.01 & 0.02 & 0.02\end{array}$ & - \\
\hline \multicolumn{6}{|l|}{ Other compounds } \\
\hline Terbuthylazine & ND $\quad$ ND $\quad 0.02 \quad 0.01$ & ND ND ND 0.02 & ND ND ND ND & ND ND ND ND & - \\
\hline $\mathrm{MCPA}^{2}$ & $\begin{array}{llll}0.06 & 0.03 & 0.05 & 0.02\end{array}$ & 0.03 ND ND 0.01 & ND ND ND ND & $0.04 \mathrm{ND}$ ND ND & $-10 * *$ \\
\hline Bentazone & $\begin{array}{llll}0.03 & 0.02 & \text { ND } & 0.02\end{array}$ & $0.01 \mathrm{ND}$ ND ND & $\begin{array}{llll}0.03 & 0.08 & 0.07 & 0.07\end{array}$ & $\begin{array}{llll}0.01 & 0.03 & 0.03 & 0.04\end{array}$ & $30020 * *$ \\
\hline $\mathrm{DNOC}^{3}$ & 0.06 ND ND ND & 0.04 ND ND ND & $0.02 \mathrm{ND}$ ND ND & 0.11 ND ND ND & - \\
\hline $\mathrm{BAM}^{4}$ & $\begin{array}{llll}0.06 & 0.01 & \text { ND } & 0.04\end{array}$ & ND ND ND ND & ND ND ND ND & ND ND ND ND & - \\
\hline Dichlorprop & ND ND ND ND & $0.02 \mathrm{ND}$ ND ND & 0.04 ND ND ND & ND ND ND ND & - \\
\hline
\end{tabular}

169 The pre and post emergence herbicides 2,4-D, atrazine, and its metabolite hydroxyatrazine

170 were the most abundantly detected species. They were found throughout all four samplings

171 and in all of the samples, with peak values of $3.00 \mu \mathrm{g} / \mathrm{L}(2,4-\mathrm{D}), 0.96 \mu \mathrm{g} / \mathrm{L}$ (atrazine), and

$1729.70 \mu \mathrm{g} / \mathrm{L}$ (hydroxyatrazine). The range of our measured concentrations is similar to results

173 from a study in the Beijing area, where herbicides in surface water were detected in

174 concentrations up to $5.1 \mu \mathrm{g} / \mathrm{L}$ (Deuerlein et al. 2001a). All of the observed peak

175 concentrations occurred in river water in May 2013. This peak time in May might be due to

176 runoff from field irrigation after the spring application of herbicides (see Figure 3 for

177 irrigation times, rainfall events, and herbicide application times), and possibly from spray

178 drift during application. Discarded containers adjacent to—or even directly into—-the river

179 might be an additional cause of the rather surprising peak in river water before the actual

180 raining season (when a stronger effect of surface runoff due to heavy rainfall events could be

181 expected). 


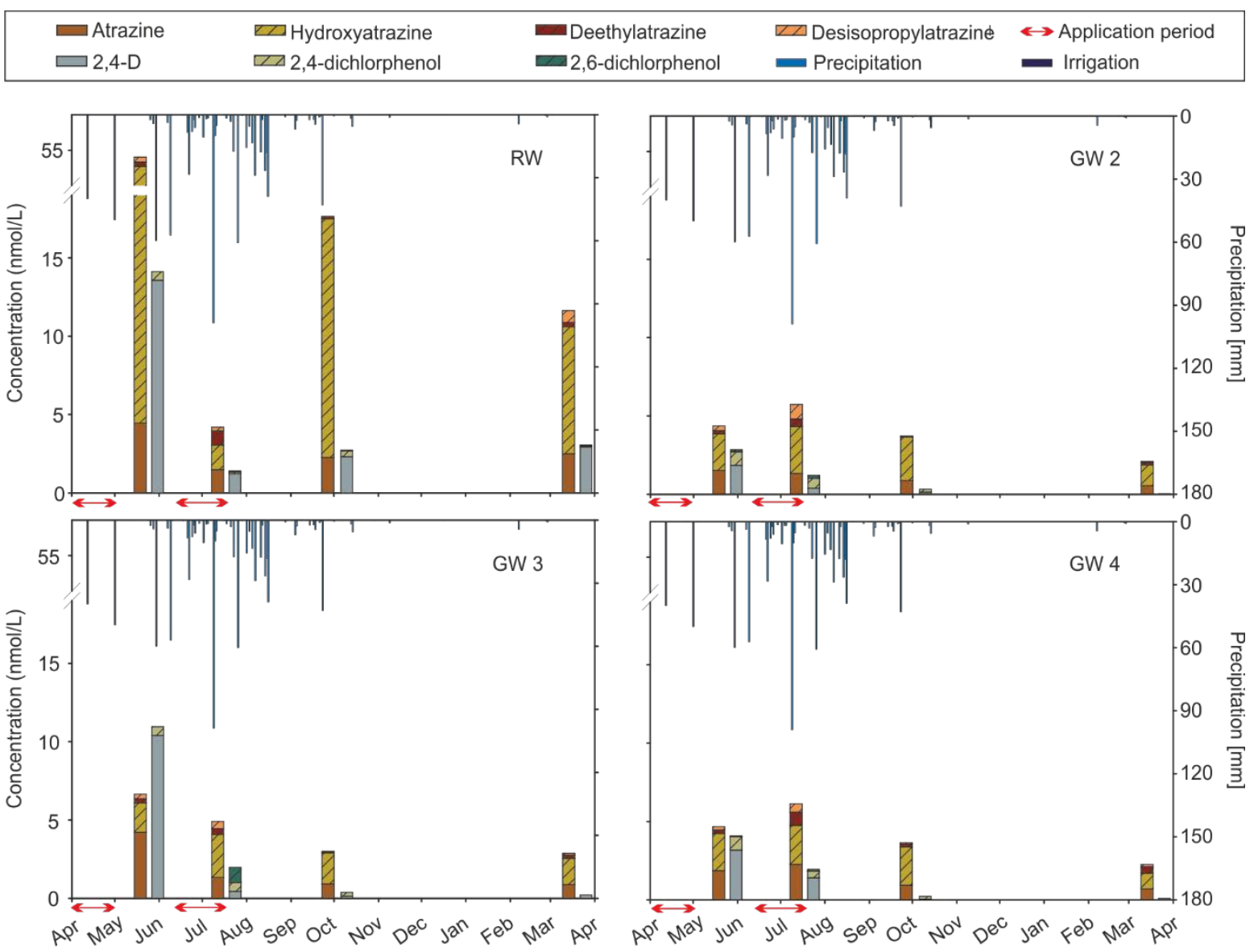

183

184

185

186

187

188

189

190

191

192

193

194

195

Fig. 3 Detections of atrazine and 2,4-D and selected degradation products and isomers for river water (RW) and groundwater (GW) samples, application periods of the herbicides, and precipitation from April 2013-April 2014. Precipitation is indicated as inverted bars on the secondary Y-axis. SINGLE-COLUMN COLOUR FIGURE

During fall and early spring, 2,4-D concentrations in river water were mostly one order of magnitude higher than in the sampled groundwater. Generally, the 2,4-D concentrations in surface remained relatively high in all samplings, and did not drop below $0.27 \mu \mathrm{g} / \mathrm{L}$ (July 2013). A sharp decrease in concentration was however observed after the peak detected in May $(3.00 \mu \mathrm{g} / \mathrm{L})$. This drop was likely caused by the high dilution of the river water that occurred just before the sampling in July (20\% of the annual rainfall). Atrazine and hydroxyatrazine also peaked in river water, but the concentrations in groundwater and river water samples were generally more similar to each other than in the case of 2,4-D, meaning that 2,4 removal along the flow path was slightly more rapid than for atrazine and its metabolites. This might indicate a higher degradation rate of 2,4-D. 
Another interesting finding was that the atrazine degradation product hydroxyatrazine

197

exceeded that of the mother compound atrazine in nearly all samples (see Figure 1 for comparison in $\mu \mathrm{mol} / \mathrm{L}$ ); even in groundwater. Other studies have found this dominance of hydroxyatrazine only in surface water, where chemical hydrolysis dominates the atrazine degradation process (Ren and Jiang, 2002a), while close to no hydroxyatrazine is usually detected in groundwater (Geng et al., 2013). Furthermore, the molar ratio of deethylatrazine over atrazine, also called DAR, in the groundwater samples was much lower than 1.0 (only 0.24 on average), which indicates that no transport through the unsaturated zone has taken place (Adams and Thurman, 1991). We therefore conclude that the much of the groundwater contamination originated from the polluted river.

Compared to the distinct peak concentrations observed after the first application period, pesticide concentrations after the summer application did not peak as considerably. This is likely due to the higher dilution factor caused by the summer rainfalls. The fact that no application of pesticides took place from about 1-2 km upstream of the study site (due to flooding of the lower reach of Fu River) might also have reduced the signal slightly.

However, the fallow stretch upstream of the site only accounts for a very small proportion of the expected source area for pesticide contamination along the river, so that it is unlikely that this caused high differences in surface water concentration compared to a year with regular farming activities. Higher vertical input of pesticides from transport through the unsaturated zone under normal field conditions could have been possible, but as the lateral inflow of the river water seemed to be the dominant influence at this site, this also would only have changed the study results to a minor extend.

In summary, the high concentration of most of the detected pesticides in river water demonstrates that there is a high potential for groundwater contamination by polluted surface 
water - despite the high dilution factor in rivers. The peak concentrations in the river water

221 are mostly observed after the pesticide application on sparse vegetation before the beginning

222 of the raining season, indicating pollution by spray drift during application (especially during application on sparse vegetation in the spring time), surface runoff, and possibly also by point sources, such as improperly disposed containers.

\subsection{Agriculture and pesticide use in the NCP}

The NCP (extending over much of the provinces Beijing, Tianjin, Hebei, Henan, Shandong,

227 Jiangsu, and Anhui in the Eastern part of China) supports 14\% of China's arable land and

$22811 \%$ of its population with only $2 \%$ of the nation's total groundwater resources (Frenken,

229 2012). The relatively fertile alluvial soils of the NCP and its mild winters with long sunshine

230 hours allow for double-cropping systems, such as the cultivation of winter wheat (October-

231 June) and summer maize (June-October). This is the dominant agricultural activity in this area

232 (Li et al., 2015). However, the strong seasonality of rainfall—of which 70-80\% occurs from

233 July to September - makes irrigation a necessity to sustain a good harvest of the winter wheat

234 (but is usually not necessary for the summer maize). Furthermore, the intense use of the soils

235 requires a major input of fertilizers to sustain high yields (Gao et al., 2014).

236 Due to the heavy promotion of agrochemicals by the government in the 1980s, and the

237 increase in time constraints of farmers due to new job opportunities outside of the agricultural

238 sector, a major shift from traditional hand weeding to the use of pesticides took place in

239 recent decades. At present, about 800 pesticide products are approved for use in China, of

240 which herbicides had an increasing share from 20\% in 1960 to 56\% in 2009 (Devi et al.,

241 2009; Zhang et al., 2011). This relative increase in the share of applied herbicides from the

242 total applied pesticides has previously been observed in the United States (US). Here, the 
243 percentage of applied herbicides rose from 18\% to 76\% between 1960 and 2008 (Fernandez-

244 Cornejo et al., 2014).

245 In the provinces of the NCP, a particularly strong trend of increasing pesticide utilization can

246 be observed. According to data from representative regions in the NCP, 93.5\% of the sown

247 area is treated with pesticides, which is well above the national average of $70.4 \%$ (Löw,

248 2003). In the specific case of winter wheat-summer maize fields, it is estimated that about

$24980 \%$ of the farmers in the NCP are using herbicides, and that only little weeding is still done

250 by hand (Menegat, 2013). Average application rates of pesticides for wheat-maize systems in

251 the NCP at the turn of the century were reported to be $2.82 \mathrm{~kg}$ a.i./ha/year ( $\mathrm{Li}$ and Zhang,

252 1999), but more recent publications report current application rates of $5.87 \mathrm{~kg}$ a.i./ha/year

253 (Wang et al., 2014).

\subsection{Pesticide handling, application, occupational risk, and farmer's knowledge}

255 A common method of pesticide application in China (and also in the NCP) is via spraying

256 from knapsack sprayers; often while wearing little protective clothing (Yang et al., 2014).

257 Consequently, a survey of 270 households in the NCP showed that $20 \%$ of the interviewed

258 farmers experience health impacts such as headache, dizziness, nausea, stomach ache, skin

259 rashes, fatigue, and increased visits to the doctor during times of pesticide application (Zhen

260 et al., 2005). On the country level, 300-500 farmers die each year because of pesticide

261 poisoning (Devi et al., 2009). A follow-up study on registered intoxications with the herbicide

262 paraquat found that — despite the widespread use of the chemical—its hazard to health is not

263 fully conceived by farmers, and many believe the compound to be less toxic than it is (Yin et

264 al., 2013). This stresses that the occupational risk from pesticides still needs to be clearly

265 understood. 
Furthermore, it is reported that pesticides are applied in very high doses, and "over

267

268

269

270

271

272

273

274

275

276

277

278

279

280

281

282

283

284

285

286

287

application is a common phenomenon in China” (Zhao, 2013). In a study on pesticide overuse on cotton, about $87 \%$ of the surveyed farmers used double or more than the recommended doses even though they claimed to have read the instructions in the manual (Jin et al. 2015). Another example is that many farmers that grow genetically modified Bt (Bacillus thuringiensis) cotton still add pesticides for pests, against which the Bt cotton is resistant (Chen et al., 2013). This overuse of pesticides has been related to a variety of reasons. Hamburger (2002) argues that mistrust into the exact composition and effectiveness of the compounds, and the misconception that higher application doses will give more protection against pest outbreaks are major causes for the observed over applications. Other studies imply that untimely spraying (when pests and diseases had already broken out), and a strong tendency to do as the neighbor does might be the cause (Liang et al., 2011). Overall, the over application indicates a lack of farmer education. Indeed, a study of 64 farming household in Hebei province discovered that $86 \%$ had never received any agricultural training (Kühl et al. 2009).

Another observed phenomenon is that emptied pesticide containers are often disposed of by simply leaving them in the field, or even in ditches and waterways. According to the China Crop Protection Industry Association (CCPIA, 2014), more than 5-10 pesticide packages per mu of farmland ( $1 \mathrm{mu}=0.06 \mathrm{ha})$ can be found on average. This may create an additional source of pesticide pollution in soil and water, and current studies propose that an enhanced farmer education as well a better infrastructure for proper disposal are needed to change the situation (Geng and Ongley, 2013; Jin et al. 2015).

\subsection{Recent and current research focus on pesticides in the NCP}


A literature review was undertaken to assess the recent and current research and monitoring of

290

291

292

293

294

295

296

297

298

299

300

301

302

303

304

pesticides in the NCP. As of today, no public national database on systematic governmental monitoring of pesticides in surface and/or groundwater could yet be found, and recent publications point out the need for the establishment of a detailed governmental environmental monitoring and risk assessment system (Han and Jin, 2016; Zhao and Pei, 2012).

In 1997, some data on sites contaminated with persistent organic pollutants (POPs), such as DDT and HCH, was published in The National Implementation Plan for the Stockholm Convention on Persistent Organic Pollutants (The People’s Republic of China, 2007). However, all data from mainland China was derived from published scientific studies only. The plan therefore highlights that a national monitoring system for persistent organic pollutants (POPs) needs to be established. The Chinese Geological Survey (CGS) conducted a groundwater quality survey from 2005-2015. Over 36,000 samples were taken and more than 70 components (including a wide range of banned and currently-used pesticides, listed in CGS, 2008) were measured over an area about 4,400,000 $\mathrm{km}^{2}$. However, this data is not publicly accessible. For routine measurements of groundwater quality, about 4000 monitoring wells (operated by CGS and the provincial government monitoring institutes) are currently in use, but pesticides are not considered for most of the wells. A more comprehensive national groundwater monitoring network (about 20,000 professional monitoring wells) is constructed at present, and over 80 components including pesticides will be measured (Hao Aibing, personal communication December 13, 2016).

Results from our literature study on non-governmental pesticide research in the NCP (Table 2, sorted by sampling year), show that ten out of seventeen studies focused on surface water pollution by HCH and DDT. These compounds had been the most widely applied pesticides in China between the 1950s and 1980s (Dai et al. 2011), but have been banned for most uses 
314 (including agriculture) by the Chinese government since 1983. A strong research focus on 315 HCH and DDT between 1970 and 1980 has previously been observed by Li and Zhang 316 (1999). Only six of our reviewed studies primarily concentrated on pesticides that are 317 currently in use. Out of these six studies, four are limited to the analysis for atrazine residues 318 only, and all the six studies have been published before or in 2004 (Deuerlein et al., 2001a; 319 Domagalski et al., 2001; Ren and Jiang, 2002a; Ren and Jiang, 2002b; Ren and Jiang, 2004; 320 Ye et al., 2001). 
Table 2 List of recent studies (1995-2013) on pesticide pollution in surface water (SW) and groundwater (GW) in the North China Plain. The studies are sorted by sampling year. Concentrations highlighted in bold exceeded the Chinese drinking water limit (according to guideline GB 5749-2006).

\begin{tabular}{|c|c|c|c|c|c|c|c|c|c|c|}
\hline \multirow{2}{*}{$\begin{array}{c}\text { Study } \\
\#\end{array}$} & \multirow[t]{2}{*}{ Pesticide } & \multirow[t]{2}{*}{ SCPOP } & \multirow[t]{2}{*}{ Study region } & \multirow{2}{*}{$\begin{array}{l}\text { Sampling time } \\
\text { (year/month) }\end{array}$} & \multicolumn{2}{|c|}{ SW - sampling } & \multicolumn{2}{|c|}{ GW - sampling } & \multirow{2}{*}{$\begin{array}{c}\text { GW } \\
\text { depth } \\
(\mathrm{m})\end{array}$} & \multirow[t]{2}{*}{ Author/year } \\
\hline & & & & & $\begin{array}{l}\text { Mean } \\
(\mu \mathrm{g} / \mathrm{L})\end{array}$ & $\begin{array}{l}\text { Range } \\
(\mu \mathrm{g} / \mathrm{L})\end{array}$ & $\begin{array}{c}\text { Mean } \\
(\mu \mathrm{g} / \mathrm{L})\end{array}$ & $\begin{array}{l}\text { Range } \\
(\mu \mathrm{g} / \mathrm{L})\end{array}$ & & \\
\hline \multirow[t]{2}{*}{1} & DDT (I) & $\mathrm{x}$ & Baiyangdian & $1995 / 06$ & 0.100 & - & - & - & - & Dou and Zhao, 1997 \\
\hline & BHC (I) & $\mathrm{x}$ & “ & “ & 0.300 & - & - & - & - & “ \\
\hline 2 & Various $^{1}$ & & Tangshan & 1996 & - & - & ND & ND & no data & Domagalski et al., 2001 \\
\hline 3 & Atrazine (I) & & Baiyangdian & 1998 & - & - & 1.33 & $0.40-3.29$ & $15-50$ & Ye et al., 2001 \\
\hline 4 & Atrazine (I) & & Yanghe & $1999-2000$ & - & ND-26.1 & - & ND-0.69 & $30-300$ & Ren and Jiang, 2002b \\
\hline 5 & Atrazine (I) & & Yanghe & 2000/12 & 6.7 & - & 0.36 & ND-0.72 & $\begin{array}{c}130 \& \\
380\end{array}$ & Ren and Jiang, 2002a \\
\hline 6 & Various $^{2}$ & & Beijing & 2001 & - & $<0.1-5.1$ & ND & ND & 100 & Deuerlein et al., 2001a \\
\hline 7 & Atrazine (I) & & Guanting* & $2002 / 03$ & 3.0 & $2.0-4.8$ & & & & Ren and Jiang, 2004 \\
\hline \multirow[t]{9}{*}{8} & Aldrin (I) & $\mathrm{x}$ & Huai'an & $2002 / 07$ & $0.005^{\mathrm{G}}$ & $0.002-0.033$ & - & - & - & Wang et al., 2009 \\
\hline & DDT (I) & $\mathrm{x}$ & “ & $-2003 / 03$ & $0.011^{\mathrm{G}}$ & $0.003-0.081$ & - & - & - & “ \\
\hline & Dieldrin (I) & $\mathrm{x}$ & “ & “ & $0.001^{\mathrm{G}}$ & $<0.001-0.002$ & - & - & - & “ \\
\hline & Endosulfan (I) & $\mathrm{x}$ & “ & “ & $0.003^{\mathrm{G}}$ & $<0.001-0.010$ & - & - & - & “ \\
\hline & Endrin (I) & $\mathrm{x}$ & “ & “ & $0.002^{\mathrm{G}}$ & $0.001-0.064$ & - & - & - & “ \\
\hline & $\operatorname{HCB}(F)$ & $\mathrm{x}$ & “ & “ & $0.003^{\mathrm{G}}$ & $<0.001-0.001$ & - & - & - & “ \\
\hline & $\mathrm{HCH}(\mathrm{I})$ & $\mathrm{x}$ & “ & “ & $0.003^{G}$ & 0.001-0.009 & - & - & - & “ \\
\hline & Heptachlor (I) & $\mathrm{x}$ & “ & “ & $0.008^{\mathrm{G}}$ & $<0.001-0.003$ & - & - & - & “ \\
\hline & Methoxychlor (I) & & “ & “ & $0.003^{\mathrm{G}}$ & $0.001-0.013$ & - & - & - & “ \\
\hline \multirow[t]{20}{*}{9} & Acetochlor (H) & & Guanting* & 2003/09\&11 & 0.001 & ND-0.002 & - & - & - & Xue and Xu, 2006 \\
\hline & Alachlor $(\mathrm{H})$ & & & $\begin{array}{c}\& \\
2004 / 05 \& 08\end{array}$ & 0.002 & ND-0.006 & - & - & - & “ \\
\hline & Aldrin (I) & $\mathrm{x}$ & “ & “ & 0.023 & $0.002-0.032$ & - & - & - & “ \\
\hline & Chlordane (I) & $\mathrm{x}$ & “ & “ & 0.010 & $0.001-0.039$ & - & - & - & “ \\
\hline & Chlorpyrifos (I) & & “ & “ & 0.002 & $<0.001-0.002$ & - & - & - & “ \\
\hline & Cypermethrin (I) & & “ & “ & 0.001 & ND-0.002 & - & - & - & “ \\
\hline & DDT (I) & $\mathrm{x}$ & “ & “ & 0.093 & $0.006-0.364$ & - & - & - & “ \\
\hline & Deltamethrin (I) & & “ & “ & 0.004 & ND-0.006 & - & - & - & “ \\
\hline & Dicofol (I) & & “ & “ & 0.001 & ND-0.003 & - & - & - & “ \\
\hline & Dieldrin (I) & $\mathrm{x}$ & “ & “ & 0.001 & ND-0.005 & - & - & - & “ \\
\hline & Endosulfans $^{3}$ (I) & $\mathrm{x}$ & “ & “ & 0.025 & $0.005-0.077$ & - & - & - & “ \\
\hline & Endrins $^{4}$ (I) & $\mathrm{x}$ & “ & “ & 0.009 & ND-0.0019 & - & - & - & “ \\
\hline & Fenvalerate (I) & & “ & “ & 0.002 & ND-0.003 & - & - & - & “ \\
\hline & HCB (F) & $\mathrm{x}$ & “ & “ & 0.012 & $0.001-0.027$ & - & - & - & “ \\
\hline & $\mathrm{HCH}(\mathrm{I})$ & $\mathrm{x}$ & “ & “ & 0.071 & $0.007-0.051$ & - & - & - & “ \\
\hline & Heptachlor (I) & $\mathrm{x}$ & “ & “ & 0.005 & $0.002-0.021$ & - & - & - & “ \\
\hline & Methoxychlor (I) & & “ & “ & 0.004 & ND-0.022 & - & - & - & “ \\
\hline & Metolachlor (H) & & “ & “ & 0.023 & $0.016-0.027$ & - & - & - & “ \\
\hline & Nitrofen $(\mathrm{H})$ & & “ & “ & 0.001 & ND-0.002 & - & - & - & “ \\
\hline & Trifluralin (H) & & “ & “ & 0.005 & 0.003-0.005 & - & - & - & “ \\
\hline \multirow[t]{2}{*}{10} & DDT (I) & $\mathrm{x}$ & Huaihe & $2007 / 03$ & 0.011 & $0.004-0.034$ & - & - & - & Feng et al., 2011 \\
\hline & $\mathrm{HCH}(\mathrm{I})$ & $\mathrm{x}$ & “ & “ & 0.004 & ND-0.013 & - & - & - & “ \\
\hline \multirow[t]{2}{*}{11} & DDT (I) & $\mathrm{x}$ & Baiyangdian & 2007/07 & 0.002 & - & - & - & - & Hu et al., 2010a \\
\hline & HCH (I) & $\mathrm{x}$ & “ & “ & 0.002 & - & - & - & - & “ \\
\hline \multirow[t]{2}{*}{12} & DDT (I) & $\mathrm{x}$ & Baiyangdian & $2007 / 10$ & ND & ND & - & - & - & Wang et al., 2013 \\
\hline & $\mathrm{HCH}(\mathrm{I})$ & $\mathrm{x}$ & “ & “ & 0.002 & $0.001-0.008$ & - & - & - & “ \\
\hline \multirow[t]{2}{*}{13} & DDT (I) & $\mathrm{x}$ & Baiyangdian & $2008 / 07$ & 0.011 & $0.004-0.021$ & - & - & - & Dai et al., 2011 \\
\hline & $\mathrm{HCH}(\mathrm{I})$ & $\mathrm{x}$ & “ & “ & 0.006 & $0.003-0.011$ & - & - & - & “ \\
\hline \multirow[t]{2}{*}{14} & DDT (I) & $\mathrm{x}$ & Weishan Lake & $2009 / 06$ & 0.096 & $0.035-0.157$ & - & - & - & Ge et al., 2010 \\
\hline & $\mathrm{HCH}(\mathrm{I})$ & $\mathrm{x}$ & “ & “ & 0.036 & 0.013-0.195 & - & - & - & “ \\
\hline 15 & $\mathrm{HCH}(\mathrm{I})$ & $\mathrm{x}$ & Baiyangdian & 2010/03-12 & 0.024 & $0.006-0.054$ & - & - & - & Dai et al., 2013 \\
\hline 16 & DDT (I) & $\mathrm{x}$ & Baiyangdian & 2010/03-12 & 0.008 & $0.002-0.034$ & - & - & - & Dai et al., 2014 \\
\hline 17 & DDT (I) & $\mathrm{x}$ & Baiyangdian & $2012 / 10$ & 0.006 & $0.003-0.017$ & - & - & - & Guo and Feng, 2014 \\
\hline & $\mathrm{HCH}(\mathrm{I})$ & $\mathrm{x}$ & “ & “ & 0.005 & 0.003-0.012 & - & - & - & “ \\
\hline
\end{tabular}

$\mathrm{x}$ indicates that the compound is listed in the SCPOP (Stockholm Convention on Persistent Organic Pollutants); Guanting* = Guanting Reservoir; $\mathrm{BHC}=$ Benzene hexachloride; DDTs = Dichlorodiphenyltrichloroethanes; HCB = Hexachlorobenzene; HCHs = Hexachlorocyclohexanes; H = Herbicide; I = Insecticide; F = Fungicide; G = Geometric mean; ND = Not detected; 1 = Complete list of analytes not known, but included the herbicides atrazine, cyanazine, simazine, alachlor, metolachlor, dicamba; $2=$ Analysis for 31 pesticides. Detected in SW: Butachlor $(\mathrm{H})$, metolachlor $(\mathrm{H})$, molinate $(\mathrm{H})$, chlorpyrifos (I), diazinon (I), and dichlorvos (I). No fungicides were detected in GW; 3 = Endosulfan I \& II + Endosulfan sulfate; 4 = Endrin + Endrin aldehyde 
331 From 2002 onward, only studies that focused primarily on HCH and DDT were found-

332 despite the fact that detected concentrations were continuously by at least one order of

333 magnitude below the Chinese drinking water limit $(1 \mu \mathrm{g} / \mathrm{L})$. One reason for the observed

334 sampling bias might be that DDT and $\mathrm{HCH}$ were listed as persistent organic pollutants (POPs)

335 by the Stockholm Convention on Persistent Organic Pollutants (SCPOP) in 2004, which could

336 have incentivized scientists to primarily publish studies on this topic. Additionally, there

337 seems to be a stronger focus on surface water than on groundwater sampling. In fact, the

338 authors could not find a published study on pesticides in groundwater in the NCP after 2002 -

339 despite the fact that Ye et al. had detected atrazine concentrations in groundwater samples that

340 exceeded the national threshold for drinking water of $2 \mu \mathrm{g} / \mathrm{L}$ in 2001 . This indicates that

341 pesticide research in the NCP has not only narrowed down to studies related to the SCPOP,

342 but also that sampling in the easier accessible surface water is preferred over groundwater

343 sampling.

344 3.5. Applied pesticides in the NCP and their potential environmental impact

345 At present, statistics on pesticide use in China are neither easily obtainable nor greatly

346 detailed (World Bank, 2010). The authors therefore identified the most commonly applied

347 pesticides for wheat-maize cropping in the NCP by means of a literature search, in which ten

348 studies were considered that referenced to specific pesticides as being "the most typically

349 applied” in the region (Table 3). 
Table 3 Most commonly applied pesticides in the North

China Plain (NCP) for winter wheat and summer maize.

The presented pesticide list is based on the identification

of different herbicides, insecticides, and fungicides in recent

literature as most abundantly used pesticides in the

wheat-maize systems of the NCP.

\begin{tabular}{|c|c|c|c|c|}
\hline \multirow{2}{*}{ Pesticide } & \multirow[t]{2}{*}{ Citation } & \multirow[t]{2}{*}{ Applied on } & \multicolumn{2}{|c|}{ Emergence } \\
\hline & & & Pre & Post \\
\hline \multicolumn{5}{|l|}{ Herbicides } \\
\hline 2,4-D & $1,2,4,6,10$ & $\mathrm{~W} / \mathrm{M}$ & & $\mathrm{x}$ \\
\hline Acetochlor & $1,3,8,9$ & $\mathrm{M}$ & $\mathrm{x}$ & \\
\hline Atrazine & $1,5,7,8,9$ & $\mathrm{~W} / \mathrm{M}$ & $\mathrm{x}$ & $\mathrm{x}$ \\
\hline Butachlor & 1,8 & $\mathrm{~W} / \mathrm{M}$ & $\mathrm{x}$ & \\
\hline Chlortoluron & 1 & $\mathrm{~W} / \mathrm{M}$ & & $\mathrm{x}$ \\
\hline Glyphosate & 1 & $\mathrm{~W} / \mathrm{M}$ & & $\mathrm{x}$ \\
\hline Iodosulfuron & 6 & $\mathrm{~W}$ & & $\mathrm{x}$ \\
\hline МСРА & 1 & $\mathrm{~W} / \mathrm{M}$ & & $\mathrm{x}$ \\
\hline Mesotrione & 8 & $\mathrm{M}$ & $\mathrm{x}$ & $\mathrm{x}$ \\
\hline Metolachlor & 8 & $\mathrm{M}$ & $\mathrm{x}$ & \\
\hline Metribuzin & 8 & $\mathrm{M}$ & $\mathrm{x}$ & $\mathrm{x}$ \\
\hline Molinate & 1 & $\mathrm{~W} / \mathrm{M}$ & $\mathrm{x}$ & $\mathrm{x}$ \\
\hline Nicosulfuron & 8 & $\mathrm{M}$ & & $\mathrm{x}$ \\
\hline Paraquat & 1 & $\mathrm{~W} / \mathrm{M}$ & & $\mathrm{x}$ \\
\hline Tribenuron-methyl & 6 & W & & $\mathrm{x}$ \\
\hline Trifluralin & 1 & $\mathrm{~W} / \mathrm{M}$ & $\mathrm{x}$ & \\
\hline Topramezone & 8 & $\mathrm{M}$ & & $\mathrm{x}$ \\
\hline \multicolumn{5}{|l|}{ Insecticides } \\
\hline Acephate & 7 & W & & \\
\hline Carbofuran & 3 & $\mathrm{M}$ & & \\
\hline Chlorpyrifos & 5 & $\mathrm{M}$ & & \\
\hline Dichlorvos & 3 & $\mathrm{~W} / \mathrm{M}$ & & \\
\hline Dimethoate & $2,3,4,10$ & $\mathrm{~W} / \mathrm{M}$ & & \\
\hline Emamectin benzoate & 5 & M & & \\
\hline Omethoate & 4 & $\mathrm{M}$ & & \\
\hline \multicolumn{5}{|l|}{ Fungicides } \\
\hline Carbendazim & 4 & $\mathrm{M}$ & & \\
\hline Chlorothalonil & 7 & $\mathrm{~W}$ & & \\
\hline
\end{tabular}

360 The results show that the different studies observed a relatively broad range of different

361 pesticides of being used in the same wheat-maize cropping systems in the NCP. Within the

362 group of herbicides, 2,4-D, acetochlor, and atrazine seem to be the most widely applied

363 compounds for weed control. This is similar to the five most used herbicides in the US:

364 glyphosate, atrazine, acetochlor, metolachlor, and 2,4-D (Fernandez-Cornejo et al., 2014).

365 Potential pesticide pollution of surface water and groundwater depends on the means and rate

366 of application, environmental factors, the physicochemical properties of the pesticide, and its

367 degradability in aquatic systems and soil. For example, high adsorption coefficients (Koc) of

368 insecticides like chlorpyrifos lead to accumulation in soil and river sediments (McKnight et

369 al., 2015; Rasmussen et al., 2015). Many herbicides on the other hand have a higher potential 
370 for leaching and runoff - not only because of their different chemical properties, but also due

371 to their early application when little vegetation is present (insecticides and fungicides are

372 normally applied on foliage). This can lead to a higher impact of spray drift during, and

373 surface runoff after the application. Accordingly, the majority of detected pesticides in large-

374 scale investigations are usually herbicides (e.g. Kolpin et al., 1998; Steele et al., 2002).

375 3.6. Transport, fate, and expected impact of 2,4- D, acetochlor and atrazine

376 Table 4 summarizes the main physicochemical properties of 2,4-D, acetochlor, and atrazine;

377 their environmental behavior that derives from these properties; and their main degradation

378 products. Acetochlor binds strongly to organic matter in the soil (Hiller et al, 2008), which

379 makes it unlikely to leach into groundwater. Additionally, studies have shown that acetochlor

380 is readily degradable in topsoil and in the subsurface (Janniche et al., 2010). Accordingly, it

381 has only rarely been detected in surface water and groundwater (Barbash et al., 1999; Kolpin

382 et al. 1996). 
Table 4 Physicochemical properties of the three herbicides 2,4-D, acetochlor, and atrazine, derived behavior in aquatic and soil systems, and main degradation products.

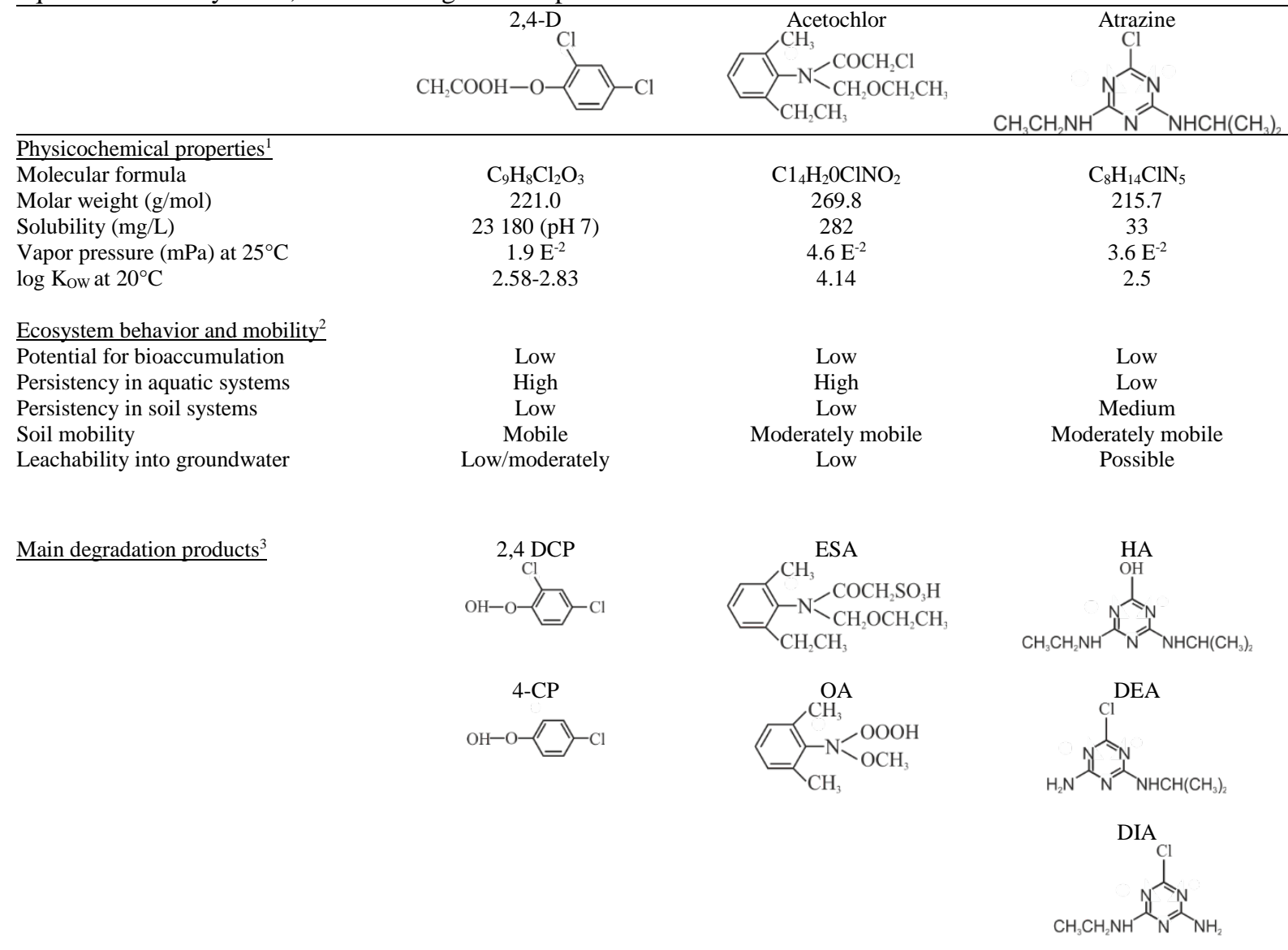

2,4-DCP = 2,4-Dichlorophenol; 4-CP = 4-Chlorophenol; ESA = Acetochlor ethanesulfonic acid; OA = Acetochlor oxanilic acid; HA = Hydroxyatrazine; DEA = Deethylatrazine; DIA = Deisopropylatrazine; 1 =Tomlin, 2009; 2 = IUPAC, 2015; 3 = Modified from Reitzel et al. 2004 (2,4-D), Janniche et al., 2010 (Acetochlor), and Vonberg et al., 2014 (Atrazine).

388 2,4-D is expected to show higher mobility in soil than acetochlor (Hiller et al., 2008), but generally has good degradability in soil, unsaturated zone and aquifer conditions (Johnson et al. 1995; Tuxen et al., 2000; Willems et al. 1996). The persistence of 2,4-D in surface water is relatively high due to its non-volatility and limited chemical and photochemical degradation (Aly et al., 1964; Loos et al., 2009; Zepp et al., 1975). 2,4-D has been sparsely detected in 393 surface water and groundwater (Domagalski et al., 2001, Rawn et al. 1999).

394 Atrazine has a moderate mobility, but higher persistence in soil, and is prone to groundwater 395 leaching (Barbash and Resek 1996; Graymore et al. 2001). This is in accordance with many 396 studies worldwide that detected atrazine and atrazine metabolites in surface water and 397 groundwater (Crocker et al., 2002; Domagalski et al., 2001; Maloschik et al., 2007; Sparling 
et al., 2010; Székács et al. 2015). The degradation process in the subsurface is slow, so that

399

400

401

402

403

404

405

406

407

408

409

410

411

412

413

414

415

416

417

418

419

420

421

atrazine residues can occasionally still be detected at the $0.1 \mu \mathrm{g} / \mathrm{L}$ threshold even 20 years after the last application (Vonberg et al., 2014). In groundwater and in the vadose zone, the degradation products hydroxyatrazine, deethylatrazine, and deisopropylatrazine usually occur

in concentrations of deethylatrazine $>$ deisopropylatrazine $>$ hydroxyatrazine (Bayless, 2001).

In surface water, hydroxyatrazine is usually detected in higher concentrations than

deethylatrazine and deisopropylatrazine, and often also in higher concentrations than the parent compound atrazine (Lerch et al., 1998; Ren and Jiang, 2002a). Under loosing stream conditions, the hydroxyatrazine concentrations in the water entering the aquifer is expected to be quickly lowered because hydroxyatrazine has been shown to readily sorb to soil and organic matter in several studies (Brouwer et al., 1990; Mandelbaum et al., 1993; Mersie and Seybold, 1996).

The pesticides atrazine and 2,4-D are regulated in both the US and the Chinese Drinking Water Guidelines. In case of long-term exposure above the maximum contamination level (MCL), atrazine is expected to cause cardiovascular and reproductive problems, and 2,4-D may cause damage to kidney, liver, adrenal glands (EPA, 2009). The two chlorinated metabolites of atrazine (deethylatrazine and deisopropylatrazine) have similar properties as atrazine, and are likewise suspected endocrine disruptors (Stanko et al., 2010; Stoker et al., 2002) with slight ecotoxicity. In terms of non-human impact, atrazine residues have been recognized as a threat to consecutive crops in double cropping systems and wild plants due to the phytotoxicity of the pesticide residues (Ren and Jiang, 2002b). This risk may be increased if surface water or groundwater used for irrigation contains atrazine residues. However (as discussed in 3.4.), only little monitoring of atrazine has recently taken place in the NCP.

\subsection{Implications for pesticide handling, management and monitoring}


422 Combined findings from our literature review and our own observations at our field site imply

423 that little knowledge of active ingredients in pesticide products and improper handling of 424 pesticides is common in many farming households in China. Point sources from carelessly 425 disposed containers remain a problem, and can be a source for soil, surface water, and 426 groundwater pollution. Therefore, more educational activities more easily accessible disposal 427 sites for pesticide containers should be offered.

428 Our field study has further shown that some of the currently applied pesticides can be 429 detected throughout different times of the year in both surface water and groundwater. 430 Polluted surface water that infiltrates into groundwater can be a source of pollution, and it is 431 advisable to treat surface water and groundwater as a joint resource by using appropriate 432 monitoring in both environmental compartments. Compared to the results from our literature 433 research, there seems to be a lacking scientific focus on currently used pesticides. We 434 therefore see a need for comprehensive monitoring program of surface water and 435 groundwater. The program should include both currently applied and banned pesticides, and 436 should be able to capture temporal variation.

437 Shallow groundwater wells and river water are often used for irrigation in the NCP. The main 438 irrigation period is typically from March to May, which coincides with our detected peak 439 concentrations of pesticides in river. Ren and Jiang (2002a) reported a decline in crop yield 440 (caused by phytotoxicity) when fields were irrigated with groundwater from 130m depth, 441 where deethylatrazine dominated as degradation product, and the total residue of atrazine and 442 chlorinated atrazine metabolites (atrazine+deethylatrazine+deisopropylatrazine) was about 9 $443 \mu \mathrm{g} / \mathrm{L}$. In our field investigation, the total chlorinated residue was comparatively low (with a 444 maximum concentration of $1.1 \mu \mathrm{g} / \mathrm{L}$ in surface water in May 2013) because hydroxyatrazine 445 was the main degradation product. Both surface water and shallow groundwater may 
therefore still be suitable for irrigation (at least in terms of atrazine and atrazine residues), but

447 monitoring of atrazine and 2,4-D is nevertheless advisable. Furthermore, the most crucial time 448 for monitoring of surface water is after the spring application of herbicides. This is in 449 accordance with the results on herbicide study in the Midwestern United States, which 450 concluded that the spring flush of herbicides in surface water might be a major contributor to 451 alluvial groundwater pollution (Thurman et al., 1991).

\section{4. Conclusion}

453 Our findings show that the three most widely used herbicides on winter wheat-summer maize 454 fields in the NCP are 2,4-D, acetochlor, and atrazine. All of these compounds are suspected to have potential negative impacts on the environment, and two of them (acetochlor and atrazine) have been banned for this reason in Europe. In our field study, 2,4-D, atrazine, and atrazine metabolites could be detected in river water and groundwater throughout the year, with peak values of $3.00 \mu \mathrm{g} / \mathrm{L}, 0.96 \mu \mathrm{g} / \mathrm{L}$, and $9.84 \mu \mathrm{g} / \mathrm{L}$, respectively. Though our study has limited repetition in time and space, we still see it as a relevant indication for the need to 460 monitor these compounds. Indeed, we found that the monitoring gap on herbicides in groundwater systems is currently closing by the on-going development of a national groundwater monitoring network, which will also be used for the monitoring of pesticides (including compounds such as atrazine and 2,4-D). Nevertheless, there is a current research bias on surface water pollution by the legacy

465 pesticides DDT and HCH, which were banned in China in the 1980s. Even though it is important to monitor if these compounds are still accumulating in the environment and/or are still illegally in use; we think that more research on currently-used pesticides should also be 
encouraged. This research should ideally include both surface water and groundwater monitoring, and should be able to catch temporal variations.

470 In addition to this, overuse and improper handling of pesticides have been observed in China 471 for a long time, and studies have been pointing out since the 1980s that better management 472 needs to be implemented. Farmer education is still poor in many areas, and infrastructure for 473 proper pesticide disposal is missing. Better farmer education, enhanced quality control, and a 474 sufficient disposal system for pesticides are highly recommended to avoid occupational risks, 475 pesticide overuse, and environmental pollution.

\section{Acknowledgements}

477 The authors would like to thank the Sino-Danish Centre for Education and Research, and the 478 Technical University of Denmark for funding this project. Special thanks go to Wenjia Wang, 479 Xiangmin Sun, Bing Zhang, Zhenyu Sun, Yilei Yu, Baogang Jiang, and Lihu Yang from the 480 Institute of Geographic Sciences and Natural Resources Research, Beijing, for their generous 481 assistance and support of the conducted field work; Farmer Ma in Dongxiangyang Village for 482 his agreement to use his land and for his help, and Fritz Hamme for language revision. 


\section{References}

484

485

486

487

488

489

490

491

492

493

494

495

496

497

498

499

500

501

502

503

Adams, C.D., Thurman, E.M., 1991. Formation and transport of deethylatrazine in the soil and vadose zone. J. Environ. Qual. 20, 540-547.

Aly, O.M., Faust, S.D., 1964. Herbicides in Surface Waters, Studies on Fate of 2,4-D and Ester Derivatives in Natural Surface Waters. J. Agric. Food Chem. 12, 541-546.

Barbash J. E. and Resek E. A. 1996. Pesticides in Groundwater. Distribution, Trends, and Governing Factors. Ann Arbor Press, Inc., Chelsea, MI

Barbash, J.E., Thelin, G.P., Kolpin, D.W., Giliom, R., 1999. Distribution of Major Herbicides in Ground Water of the United States, Water-Resources Investigations Report 98-4245. U.S. Geological Survey, Sacramento.

http://water.usgs.gov/nawqa/pnsp/pubs/wrir984245/text.html. Accessed: 10/14/2015.

Bayless, E.R., 2001. Atrazine retention and degradation in the vadose zone at a till plain site in Central Indiana. Ground Water 39, 169-180.

Brauns, B., Bjerg, P.L., Song, X., Jakobsen, R., 2016. Field scale interaction and nutrient exchange between surface water and shallow groundwater in the Baiyang Lake region, North China Plain. J. Env. Sci. (China) 45, 60-75.

Brouwer, W.W.M., Boesten, J.J.T.I., Siegers, W.G., 1990. Adsorption of transformation products of atrazine by soil. Weed Res. 30, 123-128.

CCPIA, 2014. Chinese government promotes recycling of pesticide package wastes. China Agrochemicals Newsletter December 2014, pp. 4-5. http://www.agrochemex.org/wpcontent/uploads/2015/01/China-Agrochemicals-2014-December.pdf. Accessed: 10/14/2015. 
CGS, 2008. Geological Survey Technical Standard DD 2008-01: Geological investigation and

505 evaluation of groundwater pollution. (in Chinese)

506 Chen, R., Huang, J., Qiao, F., 2013. Farmers' knowledge on pest management and pesticide 507 use in Bt cotton production in China. China Econ. Rev. 27, 15-24.

508 Crocker, P., Young, C., Bechdol, M., Rush, R., Kozak, V., Ritzky, S., Williams, K., 2002.

509 Summary of Atrazine in EPA Region 6 Surface Waters. U.S. Environmental Protection 510 Agency (Ed.), Dallas.

511 Dai, G., Liu, X., Liang, G., Han, X., Shi, L., Cheng, D., Gong, W., 2011. Distribution of 512 organochlorine pesticides (OCPs) and poly chlorinated biphenyls (PCBs) in surface water and 513 sediments from Baiyangdian Lake in North China. J. Environ. Sci. 23, 1640-1649.

514 Dai, G., Liu, X., Liang, G., Gong, W., Tao, L., Cheng, D., 2013. Evaluating the sediment515 water exchange of hexachlorocyclohexanes (HCHs) in a major lake in North China. Environ. 516 Sci. Process. Impacts 15, 423.

517 Dai, G., Liu, X., Liang, G., Gong, W., 2014. Evaluating the exchange of DDTs between 518 sediment and water in a major lake in North China. Environ. Sci. Pollut. Res. Inten. 21, 45165194526.

520 Deuerlein, U., Liu, F., Qian, C., Jiang, S., Hurle, K., 2001a. Observations of pesticides in the 521 Beijing area (air, rain and surface water), in: Lammel, G. (Ed.), Proceedings of the 522 international workshop: Slowly degradable organics in the atmospheric environment and air523 sea exchange. Hamburg, pp. 39-43.

524 https://www.mpimet.mpg.de/fileadmin/publikationen/Reports/max_scirep_335.pdf. Accessed: 525 10/14/2015 
Deuerlein, U., Liu, F., Wu, X., 2001b. Impact of pesticide use in agriculture on ground and

surface water and the atmosphere. Project report. https://www.uni-

hohenheim.de/chinaproject/publ/B3_Report_final/B3_Final_Report.pdf. Accessed:

$10 / 14 / 2015$

Devi, N.L., Qi, S., Chandra, Yadav, I.C.; Dan, Y., Fang, T., 2009. Pesticides in China and its sustainable use - Review, in: UNESCO Office Beijing (Ed.), ERSEC International

Conference Proceeding: Sustainable Land Use and Ecosystem Conservation, Beijing, pp. 107120.

Domagalski, J., Zinquan, Z., Chao, L., et al., 2001. Comparative water-quality assessment of the Hai He River Basin in the People's Republic of China and three similar basins in the United States. U.S. Geological Survey. Denver. http://pubs.usgs.gov/pp/pp1647/pdf/text.pgs610.pdf. Accessed: 10/14/2015

Dou, W., Zhao, Z., 1997. A study on bioaccumulation and biomagnification of BHC and DDT in Baiyangdian Lake foodweb. Chin. J. Environ. Sci. 18, 41-43. (in Chinese)

EPA, 2009. National primary drinking water regulations.

http://www.epa.gov/safewater/consumer/pdf/mcl.pdf. Accessed: 10/14/2015.

Feng, J., Zhai, M., Liu, Q., Sun, J., Guo, J., 2011. Residues of organochlorine pesticides (OCPs) in upper reach of the Huaihe River, East China. Ecotox. Environ. Safe. 74, 22522259.

Feng, Z., Miao, H., Zhang, F., Huang, Y., 2002. Effects of acid deposition on terrestrial ecosystems and their rehabilitation strategies in China. J. Environ. Sci. 14, 227-233.

Fernandez-Cornejo, J., Nehring, R., Osteen, C., Wechsler, S., Martin, A., Vialou, A., 2014. Pesticide Use in U.S. Agriculture: 21 Selected Crops, 1960-2008, EIB-124, U.S. Department 

of Agriculture, Economic Research Service.

550 http://www.ers.usda.gov/media/1424185/eib124.pdf. Accessed 10/13/2015.

551 Frenken, K., 2012. Irrigation in Southern and Eastern Asia in figures: Aquastat survey, 2011, 552 Food and Agriculture Organization of the United Nations (FAO), Rome.

553 Gao, Y., Wu, P., Zhao, X., Wang, Z., 2014. Growth, yield, and nitrogen use in the 554 wheat/maize intercropping system in an arid region of northwestern China. Field Crops Res. $555167,19-30$.

556 Ge, D., Han, B., Zheng, X. 2010. Research on the distribution of organochlorine pesticide in 557 the Weishan Lake and its risk evaluation. J. Anhui Agric. Sci. 38, 11987-11989, 12024. (in 558 Chinese)

Geng, Y., Ma, J., Jia, R., Xue, L., Tao, C., Li, C., Ma, X., Lin, Y., 2013. Impact of long-term 560 atrazine use on groundwater safety in Jilin Province, China. J. Integr. Agr. 12, 305-313.

561

Geng, B., Ongley, E.D., 2013. Pollution from pesticides, in: Guidelines to control water 562 pollution from agriculture in China: Decoupling water pollution from agricultural production, 563 FAO (Ed.), Rome. http://www.fao.org/docrep/019/i3536e/i3536e.pdf. Accessed: 10/14/2015

564 Graymore, M., Stagnitti, F., Allinson, G., 2001. Impacts of atrazine in aquatic ecosystems. 565 Environ. Int. 26, 483-495.

566 Guo, W., Feng, Y., 2014. Health risk assessment of organochlorine pesticides in a shallow 567 freshwater lake, China. Adv. Mat. Res. 864-867, 871-875.

568 Hamburger, J., 2002. Pesticides in China: A growing threat to food safety, public health, and 569 the environment, in: Turner, J.L. (Ed.), China Environment Series 5. Woodrow Wilson 570 Center, Washington, pp. 29-44. 
571 Han, D., Jin, S., 2016. 40 years rural environmental protection in China: Problem evolution, 572 policy response and institutional change. J. Agric. Ext. Rural Dev. 8, 1-11.

573 Hiller, E., Krascsenits, Z., Cernansky, S., 2008. Sorption of acetochlor, atrazine, 2,4-D,

574 chlorotoluron, MCPA, and trifluralin in six soils from Slovakia. Bull Environ Contam Toxicol $57580,412-416$.

576 Hou, R., Ouyang, Z., Li, Y., Wilson, G.V., Li, H., 2012. Is the change of winter wheat yield 577 under warming caused by shortened reproductive period? Ecol. Evol. 2, 2999-3008.

578 Hu, G., Dai, J., Mai, B., Luo, X., Cao, H., Wang, J., Li, F., Xu, M., 2010a. Concentrations and 579 accumulation features of organochlorine pesticides in the Baiyangdian Lake freshwater food 580 web of North China. Arch. Environ. Contam. Toxicol. 58, 700-710.

581 Hu, G., Luo, X., Li, F., Dai, J., Guo, J., Chen, S., Hong, C., Mai, B., Xu, M., $2010 b$.

582 Organochlorine compounds and polycyclic aromatic hydrocarbons in surface sediment from 583 Baiyangdian Lake, North China: Concentrations, sources profiles and potential risk. J.

584 Environ. Sci. 22, 176-183.

585 Huang, M., Liang, T., Wang, L., Zhou, C., 2015. No-tillage and fertilization management on 586 crop yields and nitrate leaching in North China Plain. Ecol. Evol. 5, 1143-1155.

587 Huang, T., Gao, B., Christie, P., Ju, X., 2013. Net global warming potential and greenhouse 588 gas intensity in a double-cropping cereal rotation as affected by nitrogen and straw 589 management. Biogeosciences 10, 7897-7911.

590 IUPAC, 2015. International Union of Pure and Applied Chemistry, 591 http://sitem.herts.ac.uk/aeru/iupac/atoz.htm. Accessed 9/24/2015. 
Janniche, G.S., Mouvet, C., Albrechtsen, H.-J., 2010. Acetochlor sorption and degradation in

593 limestone subsurface and aquifers. Pest Manag. Sci. 66, 1287-1297.

594 Jin, S., Bluemling, B., Mol, A.P., 2015. Information, trust and pesticide overuse: Interactions 595 between retailers and cotton farmers in China. NJAS - Wagen. J. Life Sc. 72-73, 23-32.

596 Johnson, W.G., Lavy, T.L., Gbur, E.E., 1995. Persistence of triclorpyr and 2,4-D in flooded 597 and nonflooded soils. J. Environ. Qual. 24, 437-497.

598 Kolpin, D.W., Goolsby, D.A., Thurman, Michael, E., 1996. Acetochlor in the Hydrologic 599 System in the Midwestern United States, 1994. Environ. Sci. Technol. 30, 1459-1464.

600 Kolpin, D.W., Barbash, J.E., Gilliom, R.J., 1998. Occurrence of pesticides in shallow 601 groundwater of the United States: Initial results from the National Water-Quality Assessment 602 Program. Environ. Sci. Technol. 32, 558-566.

603 Kühl, Y., Böber, C., Zedies, J., 2009. Water scarcity and water pollution in agriculture in the 604 North China Plain; Strategies to ensure agricultural sustainability, in: NESCO Office Beijing 605 (Ed.), International ERSEC Conference on Sustainable Land Use and Ecosystem 606 Conservation, Beijing. 279-294.

607 Lerch, R.N., Blanchard, P.E., Thurman, E.M., 1998. Contribution of hydroxylated atrazine 608 degradation products to the total Atrazine load in Midwestern Streams. Environ. Sci. Technol. $60932,40-48$.

610 Li, Y., Zhang, J., 1999. Agricultural diffuse pollution from fertilizers and pesticides in China. 611 Water Sci. Technol. 39, 25-32. 
612 Li, Z., Hu, K., Li, B., He, M., Zhang, J., 2015. Evaluation of water and nitrogen use

613 efficiencies in a double cropping system under different integrated management practices

614 based on a model approach. Agric. Water Manage. 159, 19-34.

615 Liang, W., Carberry, P., Wang, G., Lü, R., Lü, H., Xia, A., 2011. Quantifying the yield gap in 616 wheat-maize cropping systems of the Hebei Plain, China. Field Crop. Res. 124, 180-185.

617 Liu, C.; Wang, K.; Zheng, X., 2012. Responses of N2O and CH4 fluxes to fertilizer nitrogen 618 addition rates in an irrigated wheat-maize cropping system in northern China. Biogeosciences 619 9, 839-850.

620 Loos, R., Gawlik, B.M., Locoro, G., Rimaviciute, E., Contini, S., Bidoglio, G., 2009. EU621 wide survey of polar organic persistent pollutants in European river waters. Environ. Pollut. $622157,561-568$.

623 Löw, D., 2003. Crop Farming in China: Technology, Markets, Institutions and the Use of 624 Pesticides. Shaker Verlag, Aachen.

625 Maloschik, E., Ernst, A., Hegedűs, G., Darvas, B., Székács, A., 2007. Monitoring water626 polluting pesticides in Hungary. Microchem. J. 85, 88-97.

627 Mandelbaum, R.T., Wackett, L.P., Allan, D.L., 1993. Rapid hydrolysis of atrazine to 628 hydroxyatrazine by soil bacteria. Environ. Sci. Technol. 27, 1943-1946.

629 Mersie, W., Seybold, C., 1996. Adsorption and desorption of atrazine, deethylatrazine, 630 deisopropylatrazine, and hydroxyatrazine on levy wetland soil. J. Agric. Food Chem. 44, $631 \quad 1925-1929$. 
632 McKnight, U.S., Rasmussen, J.J., Kronvang, B., Binning, P.J., Bjerg, P.L., 2015. Sources,

633 occurrence and predicted aquatic impact of legacy and contemporary pesticides in streams.

634 Environ. Pollut. 200, 64-76.

635 Menegat, A., 2013. Decision Support Systems for Weed Management in North China Plain

636 Winter Wheat Production Systems. (Doctoral dissertation) University of Hohenheim.

637 http://opus.uni-hohenheim.de/volltexte/2013/842/pdf/Diss_Menegat_Alexander.pdf.

638 Accessed: 10/13/2015.

639 Menegat, A., Jäck, O., Zhang, J., Kleinknecht, K., Müller, B.U., Piepho, H.-P., Ni, H.,

640 Gerhards, R., 2013. Japanese Bindweed (Calystegia hederacea) abundance and response to

641 winter wheat seeding rate and nitrogen fertilization in the North China Plain. Weed Technol.

$642 \quad 27,768-777$.

643 Qi, Y., Wang, Z., Pei, Y., 2012. Evaluation of water quality and nitrogen removal bacteria 644 community in Fuhe River. Procedia Environ. Sci. 13, 1809-1819.

645 Rasmussen, J.J., Wiberg-Larsen, P., Baattrup-Pedersen, A., Cedergreen, N., McKnight, U.S., 646 Kreuger, J., et al., 2015. The legacy of pesticide pollution: An overlooked factor in current 647 risk assessments of freshwater systems. Water Res. 84, 25-32.

648 Rawn, D.F.K., Halldorson, T.H.J., Woychuck, R.N.; Muir, D.C.G. 1999. Pesticides in the Red 649 River and its Tributaries in Southern Manitoba: 1993-95. Water Qual. Res. J. Canada 34, 183650219.

651 Reitzel, L.A., Tuxen, N., Ledin, A., Bjerg, P.L., 2004. Can degradation products be used as

652 documentation for natural attenuation of phenoxy acids in groundwater? Environ. Sci.

653 Technol. 38, 457-467. 
654 Ren, J., Jiang, K., 2002a. Atrazine and its degradation products in surface and ground waters 655 in Zhangjiakou District, China. Chinese Sci. Bull. 47, 1612-1616.

656 Ren, J., Jiang, K., 2002b. Impact of atrazine disposal on the water resources of the Yang 657 River in Zhangjiakou area in China. Bull. Environ. Contam. Toxicol. 68, 893-900.

658 Ren, J., Jiang, K., 2004. Determination of atrazine and its degradation products in water 659 samples of Guanting reservoir. Chin. J. Anal. Lab. 23, 17-20. (in Chinese)

660 Sparling, D.W., Lindner, G., Bishop, C.A., Krest, S., 2010. Ecotoxicology of amphibians and 661 reptiles, second ed. CRC Press, New York.

662 Stanko, J.P., Enoch, R.R., Rayner, J.L., Davis, C.C., Wolf, D.C., Malarkey, D.E., Fenton, 663 S.E., 2010. Effects of prenatal exposure to a low dose atrazine metabolite mixture on pubertal 664 timing and prostate development of male Long-Evans rats. Reprod. Toxicol. 30, 540-549.

665 Steele, G.V., Johnson, H.M., Sandstrom, M.W., Capel, P.D., Barbash, J.E., 2002. Occurrence 666 and fate of pesticides in four contrasting agricultural settings in the United States. J. Environ. 667 Qual. 37, 1116-1132.

668 Stoker, T.E., Guidici, D.L., Laws, S.C., Cooper, R.L., 2002. The effects of atrazine 669 metabolites on puberty and thyroid function in the male Wistar Rat. Toxicol. Sci. 67, 198670206.

671 Strokal, M., Kroeze, C., Wang, M., Bai, Z., Ma, L., 2016. The MARINA model (Model to 672 Assess River Inputs of Nutrients to seAs): Model description and results for China. Sci. Total 673 Environ. 562, 869-888.

674 Sun, B., Zhang, L., Yang, L., Zhang, F., Norse, D., Zhu, Z., 2012. Agricultural non-point 675 source pollution in China: causes and mitigation measures. Ambio 41, 370-379. 
676 Sun, J., Feng, J., Liu, Q., Li, Q., 2010. Distribution and sources of organochlorine pesticides 677 (OCPs) in sediments from upper reach of Huaihe River, East China. J. Hazard. Mater. 184, $678 \quad 141-146$.

679 Székács, A., Mörtl, M., Darvas, B., 2015. Monitoring pesticide residues in surface and ground 680 water in Hungary: Surveys in 1990-2015. J. Chem. 2015 (1), 1-15.

681 The People’s Republic of China, 2007. National implementation plan for the Stockholm

682 Convention on Persistent Organic Pollutants.

683 http://www.pops.int/documents/implementation/nips/submissions/ china_NIP_En.pdf. 684 Accessed: 11/25/2016.

685 Thurman, E.M., Goolsby, D.A., Meyer, M.T., Kolpin, D.W., 1991. Herbicides in surface 686 waters of the midwestern United States: The effect of spring flush. Environ. Sci. Technol. 25, $687 \quad 1794-1796$.

688 Tomlin, C.D.S., 2009. The pesticide manual: A world compendium, 15th ed., British Crop 689 Protection Council, Alton.

690 Tuxen, N., Tüchsen, P.L., Rügge, K., Albrechtsen, H.-J. \& Bjerg, P.L. 2000. The fate of seven 691 pesticides in an aerobic aquifer studied in column experiments. Chemosphere, 41, 1485-1494.

692 van Oort, P., Wang, G., Vos, J., Meinke, H., Li, B.G., Huang, J.K., van der Werf, W., 2016.

693 Towards groundwater neutral cropping systems in the alluvial fans of the North China Plain. 694 Agric. Water Manag. 165, 131-140.

695 Varis, O., Vakkilainen, P., 2001. China's 8 challenges to water resource management in the 696 first quarter of the 21st Century. Geomorphology 41, 93-104. 
698 years of long-term atrazine monitoring in a shallow aquifer in western Germany. Water Res. $69950,294-306$.

700 Wang, B., Yu, G., Huang, J., Yu, Y., Hu, H., Wang, L., 2009. Tiered aquatic ecological risk 701 assessment of organochlorine pesticides and their mixture in Jiangsu reach of Huaihe River, 702 China. Environ. Monit. Assess. 157, $29-42$.

703 Wang, C., Li, X., Gong, T., Zhang, H., 2014. Life cycle assessment of wheat-maize rotation 704 system emphasizing high crop yield and high resource use efficiency in Quzhou County. J. 705 Clean. Prod. 68, 56-63.

706 Wang, Y., Wu, W., He, W., Qin, N., He, Q., Xu, F., 2013. Residues and ecological risks of 707 organochlorine pesticides in Lake Small Baiyangdian, North China. Environ. Monit. Assess. 708 185, 917-929.

709 Wei, D., Kameya, T., Urano, K., 2007. Environmental management of pesticidal POPs in 710 China: past, present and future. Environ. Intern. 33, 894-902.

711 Willems, H.P., Lewis, K.J., Dyson, J.S., Lewis, F.J., 1996. Mineralization of 2,4-D and 712 atrazine in the unsaturated zone of a sandy loam soil. Soil Biol. Biochem. 28, 989-996.

713 World Bank. 2010. Environmental impact assessment report for Hebei. s.l.; s.n..

714 http://documents.worldbank.org/curated/en/2010/09/13240415/china-second-water715 conservation-project-environmental-impact-assessment-report-vol-3-3-environmental-impact716 assessment-report-hebei. Accessed 10/13/2015.

717 Xu, F., Yang, Z., Chen, B., Zhao, Y., 2012. Ecosystem health assessment of Baiyangdian 718 Lake based on thermodynamic indicators. Procedia Environ. Sci. 13, 2402-2413. 
Xue, N., Xu, X., 2006. Composition, distribution, and characterization of suspected

720 endocrine-disrupting pesticides in Beijing Guanting Reservoir (GTR). Arch. Environ. Con.

721 Tox. 50, 463-473.

722 Yan, W., Zhang, S., Chen, X., Tang, Y., 2005. Nitrogen export by runoff from agricultural 723 plots in two basins in China. Nutr. Cycl. Agroecosyst. 71, 121-129.

724 Yang, X., Wang, F., Meng, L., Zhang, W., Fan, L., Geissen, V., Ritsema, C.J., 2014. Farmer 725 and retailer knowledge and awareness of the risks from pesticide use: a case study in the Wei 726 River catchment, China. Sci. Tot. Environ. 497-498, 172-179.

727 Ye, C., Gong, A., Wang, X., Zheng, H., Lei, Z., 2001. Distribution of atrazine in a crop-soil728 groundwater system at Baiyangdian Lake area in China. J. Environ. Sci. 13, 148-152.

729 Yin, Y., Guo, X., Zhang, S.L., Sun, C.Y., 2013. Analysis of paraquat intoxication epidemic 730 (2002-2011) within China. Biomed. Environ. Sci. 26, 509-512.

731 Zepp, R.G., Wolfe, N.L., Gordon, J.A., Baughman, G.L., 1975. Dynamics of 2,4-D esters in 732 surface waters. Hydrolysis, photolysis, and vaporization. Env. Sci. Technol. 9, 1144-1150.

733 Zhang, J., Zheng, L., Jäck, O., Yan, D., Zhang, Z., Gerhards, R., Ni, H., 2013. Efficacy of 734 four post-emergence herbicides applied at reduced doses on weeds in summer maize (Zea 735 mays L.) fields in North China Plain. Crop Prot. 52, 26-32.

736 Zhang, W., Jiang, F., Ou, J., 2011. Global pesticide consumption and pollution: with China as 737 a focus, in: Zhang, W. (Ed.), Proceedings of the International Academy of Ecology and 738 Environmental Sciences. International Academy of Ecology and Environmental Sciences 739 (IAEES), Hong Kong, pp. 125-144. 
740 Zhao, J., Guo, J., 2013. Possible trajectories of agricultural cropping systems in China from 7412011 to 2050. AJCC 02, 191-197.

742 Zhao, X., 2013. Developing an appropriate contaminated land regime in China: Lessons 743 learned from the US and UK. Springer, Berlin.

744 Zhao, Y., Pei, Y., 2012. Risk evaluation of groundwater pollution by pesticides in China: a 745 short review. 18th Biennial ISEM Conference on Ecological Modelling for Global Change 746 and Coupled Human and Natural System 13, 1739-1747.

747 Zhao, Y., Xia, X., Yang, Z., Wang, F., 2012. Assessment of water quality in Baiyangdian 748 Lake using multivariate statistical techniques. Procedia Environ. Sci. 13, 1213-1226.

749 Zhen, L., Routray, J.K., Zoebisch, M.A., Chen, G., Xie, G., Cheng, S., 2005. Three

750 dimensions of sustainability of farming practices in the North China Plain. Agric. Ecosyst.

751 Environ. 105, 507-522.

752 Zheng, M., Zheng, H., Wu, Y., Xiao, Y., Du, Y., Xu, W., Lu, F., Wang, X., Ouyang, Z., 2015.

753 Changes in nitrogen budget and potential risk to the environment over 20years (1990-2010) in 754 the agroecosystems of the Haihe Basin, China. J. Env. Sci. (China) 28, 195-202. 


\section{Appendix A - Supplementary information}

757 Table A.1 Crop activities, irrigation, and pesticide application during wheat and maize cultivation in 2012/2013.

\begin{tabular}{|c|c|c|c|c|c|c|c|}
\hline & \multirow[t]{2}{*}{ Date } & \multicolumn{2}{|c|}{ Crop activities } & \multirow{2}{*}{$\frac{\text { Irrigation }}{(\mathrm{mm})}$} & \multicolumn{3}{|c|}{ Pesticide application (g/ha of active ingredient) } \\
\hline & & Seeding & Harvest & & Type of pesticide & Application & $\begin{array}{c}\text { Recommended } \\
\text { application* }\end{array}$ \\
\hline \multirow[t]{11}{*}{ Winter wheat } & 10 Oct 2012 & + & & & & & \\
\hline & 12 Apr 2013 & & & 40 & & & \\
\hline & 20 Apr 2013 & & & & Tribenuron-methyl (H) & 18 & $9-18$ \\
\hline & 01 May & & & 50 & & & \\
\hline & 2013 & & & 50 & & & \\
\hline & 30 May & & & 60 & & & \\
\hline & 2013 & & & 00 & & & \\
\hline & 03 June & & & & Dimethoate (I) & 75 & $50-100$ \\
\hline & 2013 & & & & & & \\
\hline & 10 June & & + & & & & \\
\hline & 2013 & & $T$ & & & & \\
\hline \multirow{6}{*}{$\begin{array}{l}\text { Summer } \\
\text { maize }\end{array}$} & 12 June & + & & & & & \\
\hline & 2013 & + & & & & & \\
\hline & 07 June & & & & Paraquat (H) & 1000 & $600-900$ \\
\hline & 2013 & & & & & & \\
\hline & & & & & Acetochlor (H) & 2100 & $1800-3750$ \\
\hline & 05 Oct 2013 & & + & & & & \\
\hline
\end{tabular}

*recommendation as stated on the pesticide container

760 Table A.2 Full set of analyzed compounds from the four field campaigns for river water (RW) and groundwater

$761(\mathrm{GW})$ samples. All detection limits were $0.01 \mu \mathrm{g} / \mathrm{L}$

\begin{tabular}{|c|c|c|c|c|c|c|c|c|c|c|c|c|c|c|c|c|}
\hline \multirow[t]{2}{*}{ Pesticide (all values in $\mu \mathrm{g} / \mathrm{L}$ ) } & \multicolumn{4}{|c|}{29 May 2013} & \multicolumn{4}{|c|}{22 July 2013} & \multicolumn{4}{|c|}{07 October 2013} & \multicolumn{4}{|c|}{25 March 2014} \\
\hline & RW & GW2 & GW3 & GW4 & RW & GW2 & GW3 & GW4 & RW & GW2 & GW3 & GW4 & RW & GW2 & GW3 & GW4 \\
\hline \multicolumn{17}{|l|}{ Triazine-herbicides } \\
\hline Atrazine & 0.96 & 0.33 & 0.91 & 0.40 & 0.32 & 0.29 & 0.29 & 0.49 & 0.49 & 0.19 & 0.20 & 0.20 & 0.54 & 0.12 & 0.19 & 0.15 \\
\hline - Desethylatrazine (M) & 0.07 & 0.04 & 0.05 & 0.04 & 0.17 & 0.09 & 0.07 & 0.16 & 0.03 & 0.01 & 0.02 & 0.04 & 0.05 & 0.03 & 0.04 & 0.08 \\
\hline - Deisopropylatrazine (M) & 0.07 & 0.05 & 0.05 & 0.04 & 0.04 & 0.16 & 0.08 & 0.09 & ND & ND & ND & 0.01 & 0.13 & 0.01 & 0.02 & 0.02 \\
\hline - Hydroxyatrazine (M) & 9.70 & 0.46 & 0.37 & 0.47 & 0.31 & 0.59 & 0.54 & 0.49 & 3.00 & 0.55 & 0.39 & 0.48 & 1.60 & 0.26 & 0.33 & 0.20 \\
\hline Cyanazine & ND & ND & ND & ND & ND & ND & ND & ND & ND & ND & ND & ND & ND & ND & ND & ND \\
\hline Simazine & ND & ND & ND & ND & ND & ND & ND & ND & ND & ND & ND & ND & ND & ND & ND & ND \\
\hline Terbutylazine & ND & ND & 0.02 & 0.01 & ND & ND & ND & 0.02 & ND & ND & ND & ND & ND & ND & ND & ND \\
\hline \multicolumn{17}{|l|}{ Phenoxy-herbicides } \\
\hline $2,4-D^{1}$ & 3.00 & 0.41 & 2.30 & 0.70 & 0.27 & 0.09 & 0.10 & 0.31 & 0.51 & 0.03 & 0.03 & 0.01 & 0.65 & 0.01 & 0.05 & 0.02 \\
\hline - 2,4-dichlorphenol (M) & 0.09 & 0.14 & 0.09 & 0.14 & 0.02 & 0.10 & 0.09 & 0.07 & 0.06 & 0.03 & 0.04 & 0.03 & 0.01 & ND & ND & ND \\
\hline - 2,6-dichlorphenol (I) & ND & 0.02 & ND & 0.01 & 0.01 & 0.03 & 0.16 & 0.02 & 0.01 & ND & ND & ND & 0.01 & ND & ND & ND \\
\hline $\mathrm{MCPA}^{2}$ & 0.06 & 0.03 & 0.05 & 0.02 & 0.03 & ND & ND & 0.01 & ND & ND & ND & ND & 0.04 & ND & ND & ND \\
\hline - 4-chlor-2-methylphenol (M) & ND & ND & ND & ND & ND & ND & ND & ND & ND & ND & ND & ND & ND & ND & ND & ND \\
\hline Dichlorprop & ND & ND & ND & ND & 0.02 & ND & ND & ND & 0.04 & ND & ND & ND & ND & ND & ND & ND \\
\hline Mecoprop & ND & ND & ND & ND & ND & ND & ND & ND & ND & ND & ND & ND & ND & ND & ND & ND \\
\hline \multicolumn{17}{|l|}{ Other herbicides } \\
\hline Bentazon & 0.03 & 0.02 & ND & 0.02 & 0.01 & ND & ND & ND & 0.03 & 0.08 & 0.07 & 0.07 & 0.01 & 0.03 & 0.03 & 0.04 \\
\hline Dichlobenil & ND & ND & ND & ND & ND & ND & ND & ND & ND & ND & ND & ND & ND & ND & ND & ND \\
\hline - $\mathrm{BAM}^{3}(\mathrm{M})$ & 0.06 & 0.01 & ND & 0.04 & ND & ND & ND & ND & ND & ND & ND & ND & ND & ND & ND & ND \\
\hline Dinoseb & ND & ND & ND & ND & ND & ND & ND & ND & ND & ND & ND & ND & ND & ND & ND & ND \\
\hline DNOC $^{4}$ & ND & ND & ND & ND & ND & ND & ND & ND & ND & ND & ND & ND & ND & ND & ND & ND \\
\hline Hexazinone & 0.06 & ND & ND & ND & 0.04 & ND & ND & ND & 0.02 & ND & ND & ND & 0.11 & ND & ND & ND \\
\hline Isoproturon & ND & ND & ND & ND & ND & ND & ND & ND & ND & ND & ND & ND & ND & ND & ND & ND \\
\hline Metamitron & ND & ND & ND & ND & ND & ND & ND & ND & ND & ND & ND & ND & ND & ND & ND & ND \\
\hline Pendimethalin & ND & ND & ND & ND & ND & ND & ND & ND & ND & ND & ND & ND & ND & ND & ND & ND \\
\hline
\end{tabular}

